\title{
Меланома шкіри: від майже невидимої до візуально незаперечної. Окремі принципи керівництва та огляд клінічних випадків
}

Меланома - злоякісна пухлина, що виникає з меланоцитів, яка частіше вражає шкіру, а також може виникати на рогівці, кон'юнктиві, циліарному тілі та будь-яких місцях, де локалізована слизова оболонка. Меланома $\epsilon$ однією з найнебезпечніших пухлин внаслідок здатності до стрімкого непрогнозованого метастазування. В Україні, згідно з даними Національного канцер-реєстру, захворюваність у 2018-2019 рр. становила 7,9 випадків на 100 тис. населення. Найважливішим фенотипічним фактором ризику меланоми вважають шкіру, схильну до виникнення сонячних опіків. Вона має генетичну детермінанту у вигляді спадкового варіанта рецептора меланокортину-1, що бере участь у пухлинному процесі. Меланома шкіри поділяється на in situ та інвазивну, що відрізняються локалізацією атипових клітин у межах епідермісу та у нижчерозміщених тканинах відповідно. У свою чергу, серед інвазивних форм виділяють чотири найпоширеніших типи: поверхнево-поширену, нодулярну, меланому зі злоякісного лентиго та акральну. Діагностика меланоми ґрунтується, перш за все, на клінічному огляді хворого. Проте з метою раннього виявлення може бути використана дерматоскопія. ї̈ застосування вимагає від спеціаліста комплексу знань та навиків, що поступово зростають із досвідом практичної роботи. Очікуваними ознаками є: атипова пігментна мережа, хаотично розміщені коричнево-чорні пігментні глобули чи точки, асиметрично розміщені ділянки різнобарвної пігментації, біло-блакитна вуаль, поліморфний судинний малюнок. У разі виявлення підозрілого утворення потрібне його видалення з подальшою гістологічною верифікацією. Якщо гістологічний діагноз викликає сумніви, додаткову інформацію можна отримати від імуногістохімії. У публікації представлено огляд випадків захворювання на різні форми меланоми шкіри. Частина з них макроскопічно очевидні, інші підтверджено дерматоскопічно. Матеріал проілюстровано мікрофотографіями з детальним описом візуалізованих структур. Коротко узагальнено рекомендації щодо спостереження пацієнтів із цією патологією.

Ключові слова: меланома, діагностика, дерматоскопія, спостереження, лікування.

\section{Вступ}

Меланома - злоякісна пухлина, що виникає з меланоцитів, яка частіше вражає шкіру, а також може виникати на рогівці, кон'юнктиві, циліарному тілі та будь-яких місцях, де локалізована слизова оболонка. Зазвичай ця пухлина схильна до продукування пігменту, проте близько $2 \%$ утворень такого типу можуть містити незначні включення меланіну чи взагалі бути позбавлені від нього (Pizzichetta M.A. et al., 2004). Меланома - одна з найнебезпечніших пухлин внаслідок здатності до стрімкого непрогнозованого метастазування. В Україні, згідно з даними Національного канцер-реєстру, захворюваність у 2018-2019 рр. становила 7,9 випадків на 100 тис. населення. В інших країнах цей показник знаходиться на дещо вищому рівні. Перш за все така ситуація очікувана в місцях, де населення зі світлою шкірою піддається тривалій активній інсоляції, зокрема в Австралії цей показник становить до 50 нових випадків на рік. Протягом останніх років відзначають тенденцію до зростання показників, що, імовірно, збережеться і в майбутньому (Whiteman D.C. et al., 2016).

Найважливішим фенотипічним фактором ризику меланоми вважають шкіру, схильну до виникнення сонячних опіків. Вона має генетичну детермінанту у вигляді спадкового варіанта рецептора меланокортину-1, що бере участь у пухлинному процесі (Herraiz C. et al., 2017). Також вищий ризик у осіб з великою кількістю вроджених чи набутих пігментних невусів, що проявляють ознаки атиповості (диспластичні невуси) (Bauer J., Garbe C., 2003). Особливої уваги потребують особи, що мають меланоцитарні пухлини в анамнезі, та члени їх родин. Основний екзогенний канцерогенний фактор - ультрафіолетове опромінення (Mitra D. et al., 2012; Vuong K. et al., 2020).
Меланома шкіри поділяється на in situ та інвазивну, що відрізняються локалізацією атипових клітин у межах епідермісу та у нижчерозміщенихтканинахвідповідно. Усвоючергу, середінвазивних форм виділяють чотири найпоширеніших типи: поверхнево-поширену, нодулярну, меланому зі злоякісного лентиго та акральну.

Акральна меланома є рідкісною серед населення європеоїдної раси, проте у представників негроїдної раси вона може становити до половини від усіх випадків, що виникають (Soyer H.P. et al., 2007).

Поверхнево-поширена меланома (superficial spreading melanoma) клінічно проявляється як пляма, що повільно переростає у бляшку, часто сформовану поєднанням ділянок із неоднорідним чи нерівномірним забарвленням, які перемежовуються блідими ділянками регресу. На цей вид припадає до 41\% загальної кількості виявлених пухлин (рис. 1).

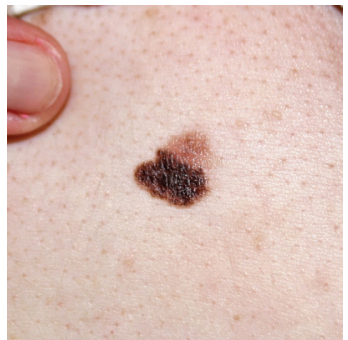

Рис. 1. Поверхнево-поширена меланома

Нодулярна меланома (nodular melanoma) - вузлова, екзофітна, коричнево-чорна, ерозована, кровоточива пухлина (16\% випадків) (рис. 2). 


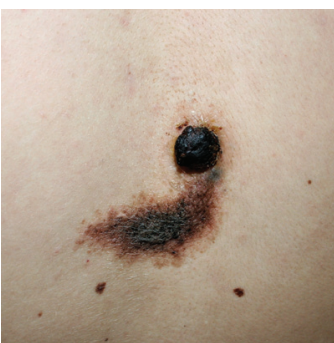

Рис. 2. Нодулярна меланома

Меланома зі злоякісного лентиго (lentigo maligna melanoma), або лентигіозна форма, - повільно зростаюча прогресивна інвазія злоякісного лентиго (меланома in situ). Переважно виникає на пошкодженому сонцем обличчі людей літнього віку (до 14\% випадків) і має вигляд плями з відсутнім чи слабовираженим рельєфом стосовно довколишньої шкіри (рис. 3).

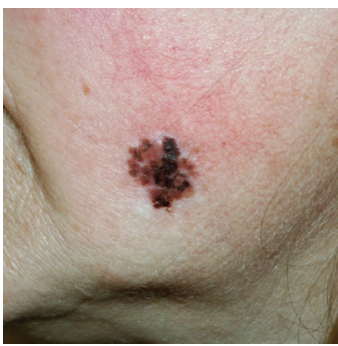

Рис. 3. Меланома зі злоякісного лентиго

Акральна лентигінозна меланома (acral lentiginous melanoma) - типово виникає в піднігтьовій та долонно-підошовній локалізації. У початковій стадії проявляється нерегулярною, погано відмежованою пігментацією, пізніше нодулярна ділянка відображає патерн інвазивного росту (до 5\% випадків).

Десмопластична меланома (desmoplastic melanoma) - рідкісний тип (1-4\% випадків), при якому ріст злоякісної клітини супроводжується розростанням фіброзної чи сполучної тканини, тому клінічно тривалий час такі новоутворення можуть виглядати доброякісно.

Ще один рідкісний тип меланоми - амеланотична форма (amelanotic melanoma) з невеликим або відсутнім вмістом пігменту не лише на макроскопічному, а і мікроскопічному рівні. Амеланотична меланома зазвичай асоціюється з вузловими і десмопластичними підтипами та частіше локалізується на вусі, носі, обличчі та шкірі тулуба.

Клініко-гістологічні підтипи меланом не мають прогностичного значення щодо перебігу хвороби (Garbe C. et al., 2020a).

Класифікація меланоми Всесвітньої організації охорони здоров'я 4-го перегляду 2018 р. укладена на підставі концепції патогенезу та ступеня накопиченої шкоди від сонця, що визначено за ступенем сонячного еластозу на біопсії. На підставі цього меланоми поділяють на такі, що виникають на шкірі, яка піддається впливу сонця, та ті, що виникають на захищених від сонця ділянках чи без відомої етіологічної асоціації із впливом ультрафіолетового випромінювання (таблиця) (Elder D.E. et al., 2018).

Таблиця. Класифікація меланоми Всесвітньої організації охорони здоров'я 4-го перегляду (фрагмент)

Меланома, що виникає 3 низьким показником CSD (поверхнево-поширена на шкірі, яка піддається та окремі нодулярні меланоми)

впливу сонця

3 високим показником CSD (меланома зі злоякісного лентиго та окремі нодулярні меланоми)

Десмопластична меланома

Меланома, що виникає Меланома з невуса Шпіца

на захищених від сонця Акральна меланома

ділянках чи без відомої Меланома на слизових оболонках

етіологічної асоціації Меланома із вродженого невуса

із впливом ультрафіолето- Меланома із блакитного невуса

вого випромінювання Увеальна меланома

CSD - ступінь накопиченої шкоди від сонця (Cumulative Sun Damage).

Діагностика меланоми ґрунтується перш за все на клінічному огляді хворого. Типові ознаки - це асиметрія утворення, нечіткі межі, мультиколірність, неоднорідність чи нерівномірність забарвлення, діаметр понад 5 мм, наявність динамічних змін у до- рослому віці. Проте, коли пухлина стає макроскопічно очевидною, це може погіршувати прогноз хворого.

Прогностичні біомаркери є предметом багатьох досліджень, проте, окрім рівня лактатдигідрогенази у сироватці крові, жоден з них не має достатньої клінічної валідації для рутинного використання (Gogas H. et al., 2009).

3 метою раннього виявлення меланоми може бути застосована конфокальна лазерна скануюча мікроскопія, однак вона малодоступна на території нашої держави, тому рекомендується використання дерматоскопії. При правильному застосуванні ефективність огляду за допомогою дерматоскопа зростає у 9 разів порівняно з обстеженням неозброєним оком. Чутливість щодо меланоми шкіри становить 87\% порівняно із 69\% для макроскопічного обстеження, тоді як специфічність знаходиться на однаковому рівні (Lee K.J. et al., 2020).

Проведення дерматоскопії вимагає від спеціаліста комплексу знань та навиків, які вдосконалюються в процесі набуття досвіду практичної роботи. Очікуваними ознаками будуть: атипова пігментна мережа, хаотично розміщені коричнево-чорні пігментні глобули чи точки, асиметрично розміщені ділянки різнобарвної пігментації, біло-блакитна вуаль, поліморфний судинний малюнок.

Діагностика безпігментної меланоми пов'язана з певними труднощами, оскільки з характерних ознак для неї властиві лише поліморфні судини (Garbe C. et al., 2020a).

Для меланоми, яка розвивається на фоні злоякісного лентиго, характерними є 4 стадії розвитку пухлини. На першій стадії пігментацію формує точковий малюнок, розміщений довкола волосяних фолікулів; на другій - відбувається злиття з утворенням ромбовидних структур; на третій стадії - утворюються гомогенні структури, що відділяють волосяні фолікули; на завершальній стадії ділянки проліферації атипових меланоцитів займають простір усередині фолікулів з утворенням суцільних зон, отвори додатків шкіри визначаються лише на периферії утворення (рис. 4) (Stolz W. et al., 2002).

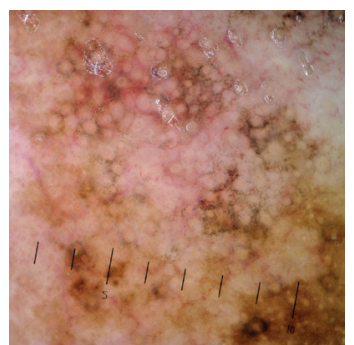

Рис. 4. Дерматоскопія з використанням світлопровідної рідини. Ділянка шкіри обличчя. Фрагмент меланоми зі злоякісного лентиго. Різні зони демонструють стадії від I до IV за Штольцом

Малюнок паралельних гребенів та наявність нерегулярних дифузних пігментацій є типовою ознакою малігнізації, характерною для акральної меланоми, де типовими в силу особливостей анатомічної будови шкіри є патерни паралельних борозен, волокон, решітчастих комірок (рис. 5).

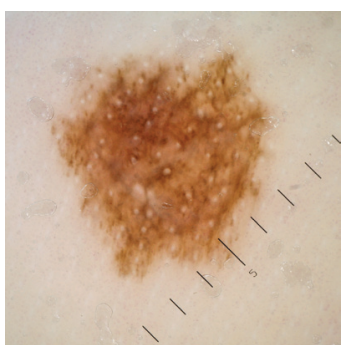

Рис. 5. Дерматоскопія з використанням світлопровідної рідини. Ділянка шкіри ступні. Нерегулярна дифузна пігментація, нетипова для цієї анатомічної ділянки

На жаль, не завжди вся вищеописана клінічна симптоматика меланоми може бути чітко відстежена, тому виникла потреба в розробленні системи правил, які допомогли би прийняти правильне рішення в сумнівних випадках. За час розвитку дерматоскопії розроблено кілька підходів до аналізу зображень, які ґрунтувалися на мультицентрових ретроспективних дослід- 
женнях. Це аналіз структур, правило АBCD, 7-точковий контрольний список, 3-точковий контрольний список, метод Мензеса, «Хаос і натяки» як варіант переглянутого аналізу структур, TADA-алгоритм, метод кольорового колеса, контрольний список BRAFF для акральної меланоми. Усі ці алгоритми мають свої переваги та винятки і, можливо, варто ознайомитися з кожним із них для того, щоб вибрати найбільш зручний у повсякденній роботі. Детальну інформацію про них неважко відшукати в науковій періодиці та спеціалізованій літературі.

З розвитком цифрової дерматоскопії ми отримали можливість динамічного спостереження за утвореннями шкіри. Проте ухворих із великою кількістю невоїдних утворень значну проблему може становити виявлення нових висипань. Тут у пригоді стає використання загальних фотографій тіла (total body photography), при цьому особливо зручним $€$ їх поєднання з можливостями штучного інтелекту, що дозволяє спростити роботу лікаря-спеціаліста, поклавши на програмні засоби роботу з відбору «гидкого каченяти» (Salerni G. et al., 2012; Primiero C.A. et al., 2019).

У разі виявлення підозрілого утворення виникає необхідність його хірургічного видалення з подальшою гістологічною верифікацією. Важливою у звіті патогістолога буде інформація про клініко-патогістологічний тип пухлини, глибину інвазії за Бреслоу, звиразкування, кількість мітозів на 1 мм² , наявність мікросателітів у навколишній шкірі, а також додаткової інформації про фазу росту, регрес, периневральну, лімфо- та гематоваскулярну інвазію чи емболізацію (Ruiter D.J. et al., 2002).

У сумнівних випадках, коли гістологічний діагноз не дає чіткої відповіді щодо характеру патологічного процесу, додаткову інформацію можна отримати шляхом імуногістохімічного дослідження матеріалу пухлини (маркери S-100, Melan-A, HMB45, SOX10). Необхідно враховувати, що матеріал пухлини є неоднорідним, оскільки злоякісна тканина росте хаотично. У разі недостатньої кількості патогістологічних зрізів, отриманих для дослідження, чи при неправильній методології їх виконання, існує ризик пропустити патологічно змінену ділянку. У таких випадках важливим $€$ тісний контакт між патогістологом та лікарем-клініцистом, спільні зусилля яких покликані встановити правильний діагноз та, відповідно, забезпечити адекватне ведення хворого.

\section{Клінічний випадок № 1}

Наведемо клінічний приклад ранньої діагностики.

Хвора А., 36 років. Обтяжений анамнез щодо меланоми в родині. На контрольному огляді виявлена нова пігментна пляма на тулубі, біля 3 мм у діаметрі, що, зі слів хворої, з'явилася протягом останнього року. Макроскопічно не становила інтересу. Колір і структура утворення без особливостей, на поверхні незначне лущення. При дерматоскопії без застосування світлопровідної рідини відзначається неоднорідна пляма розміром $2 \times 1,5$ мм, картина нечітка внаслідок посиленого шкірного малюнка та луски. У периферичній ділянці переважають різнобарвні пігментні глобули, що формують більш інтенсивно забарвлені сектори утворення. У центральній ділянці та по решті секторахпігментація менш інтенсивна та відносно однорідна (рис. 6).

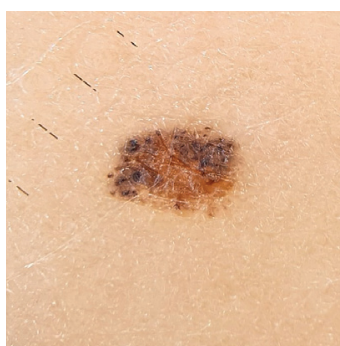

Рис. 6. Хвора А. Дерматоскопія утворення в ділянці тулуба без застосування світлопровідної рідини

Після нанесення дерматоскопічної олії візуалізація шкірного елементу покращилася. Чітко видно дисхромію пігментних структур. Глобули, розміщені у краєвій ділянці, візуалізуються на дифузному, різному за інтенсивністю та забарвленням фоні. Така локалізація глобул є типовою для шпіцоїдних утворень і за наявності променистого малюнка формує патерн «зоряного вибуху», проте в цій ситуації, імовірно, є ознакою інтенсифікації росту утворення (рис. 7).

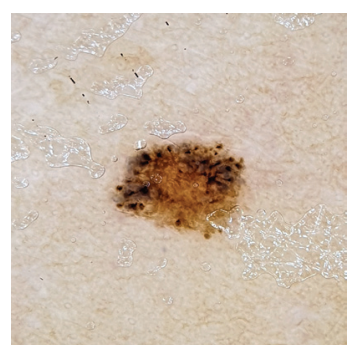

Рис. 7. Хвора А. Дерматоскопія утворення в ділянці тулуба із застосуванням світлопровідної рідини

Хвору направлено на хірургічне видалення утворення з підозрою на поверхнево-поширену меланому шкіри чи пізній невус Шпіца. Здійснене щадне видалення. Патогістологічно в ексцизійному матеріалі виявлена виражена проліферація атипових меланоцитів, розміщених у вигляді поодиноких клітин та груп, переважно вздовж дермо-епідермального з'єднання (I ступінь інвазії за Кларком), наявні ознаки педжетоїдного розповсюдження поодиноких пухлинних клітин. Звиразкування епідермісу не визначається. Меланоцити з ознаками вираженої цитологічної атипії, поліморфізмом, частина ядер везикулярні з базофільним ядерцем, частина має гіперхромні, ангулярні ядра, фігури мітозу відсутні. У дермі вогнищева лімфоцитарна інфільтрація з домішками меланофагів. Морфологічна будова утвору відповідає меланомі in situ з I ступенем інвазії за Кларком (рис. 8).

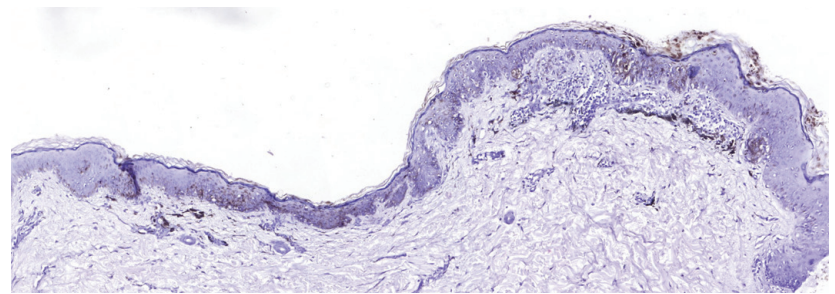

Рис. 8. Хвора А. Мікроскопія фрагменту ексцизійного матеріалу. Шкіра ділянки тулуба. Меланома in situ

Додатково проведено повторне широке висічення післяопераційного рубця і довколишньої шкіри. За результатами гістологічного дослідження ознак пухлинного росту в межах резектованого матеріалу не виявлено. Рубцювання тканин проходило без особливостей. Хвора проходить контрольні огляди двічі на рік.

При описаній товщині пухлини питання щодо наявності метастатичних вогнищ практично виключається та на подальших етапах немає необхідності в регулярних, тривалих та високовартісних обстеженнях. Проте коли виявляємо ознаки інвазії пухлини і коли вони клінічно очевидні, це значною мірою погіршує прогноз.

\section{Клінічний випадок № 2}

Наведемо клінічний приклад меланоми, що розвинулася зі злоякісного лентиго.

Хвора Б., 64 роки. Протягом тривалого часу спостерігала на обличчі пляму, що поступово збільшувалася в розмірах та змінювала забарвлення. Хвору вона впродовж тривалого часу не турбувала, проте протягом останніх місяців неодноразово травмувалася і кровоточила. Макроскопічно в ділянці правої щоки різнобарвна, неправильної форми, безструктурна пляма розміром до 10 см у діаметрі з кратероподібною виразкою в центрі (рис. 9).

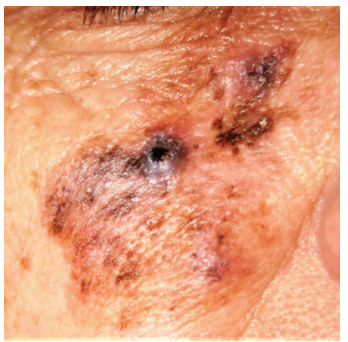

Рис. 9. Хвора Б. Фрагмент шкіри правої щоки. Звиразкування. Злоякісне лентиго 
Ситуація клінічно очевидна, проте при дерматоскопії спостерігаємо картину різних стадій формування меланоми зі злоякісного лентиго за Штольцом. У проміжках дисхромія, зони регресу, рубцювання, поодинокі білі кола, поліморфний судинний малюнок (рис. 10). У центральній частині утвору кратероподібна виразка, навколишні тканини синьо-сірі, імовірно, за рахунок глибокого залягання пігментних структур (рис. 11). Така особливість утворення, очевидно, свідчить про інвазивний ріст.

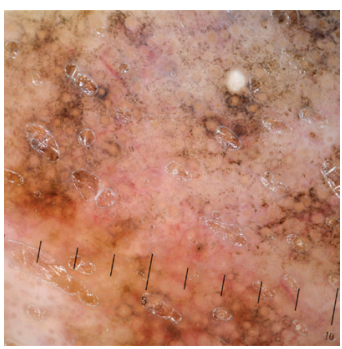

Рис. 10. Хвора Б. Дерматоскопія із застосуванням світлопровідної рідини. Фрагмент утворення на правій щоці

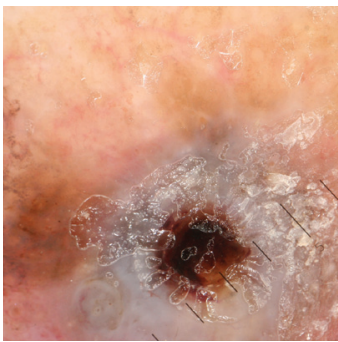

Рис. 11. Хвора Б. Дерматоскопія із застосуванням світлопровідної рідини Фрагмент утворення на правій щоці з кратероподібною виразкою

Наявність регіонарних метастатичних вогнищ, що не піддаються видаленню, чи віддалених метастазів раніше було абсолютним невідворотним вироком для хворого. Проте завдяки розвитку медичної науки з'явилися нові дані щодо онкогенезу меланоми та запропоновано нові високотехнологічні методи таргетної та імунотерапії, засновані на застосуванні препаратів - моноклональних антитіл до молекулярних факторів росту меланоми. Перед призначенням цього лікування з метою визначення його потенційної ефективності та раціонального вибору препаратів таргетної терапії необхідно виконати молекулярну діагностику щодо встановлення статусу BRAF V600-мутації. İ̈̈ проводять на тканині первинної пухлини чи матеріалі з метастатичних вогнищ. Також необхідно зважати, з урахуванням поліклональної моделі меланоми, що можливість різного статуcy BRAF-мутації в первинному та метастатичних вогнищах становить 13\% (Valachis A., Ullenhag G.J., 2017). При позитивному результаті пухлина буде чутливою до застосування BRAFта MEK-інгібіторів. Менш поширеними є мутації генів NRAS та c-KIT, зараз ведуться інтенсивні дослідження з розроблення та апробації їніх інгібіторів. Інтерферон- $\alpha_{2}$ тривалий час був препаратом першої лінії для ад'ювантної терапії в разі меланоми, незважаючи на встановлені дані щодо токсичності. Проте з огляду на результати проведених досліджень із CTLA-4 та PD1-антитілами, BRAF- і MEK-інгібіторами, які доводять їх кращу ефективність, застосування інтерферону- $\alpha$ не рекомендується (Garbe C. et al., 2020b). Хоча варто зважити на високу вартість та обмежену доступність новітніх схем лікування у нашій країні.

\section{Клінічний випадок № 3}

Наведемо ще один клінічний приклад, де макроскопічно утворення становило незначний інтерес, а діагноз встановлено за допомогою дерматоскопії.

Хвора В., 35 років. Звернулася на обстеження з приводу наявності множинних пігментних утворень на шкірі. Часто працює на відкритому сонці, застосовує захисний одяг, проте шкіра ділянок обличчя, попереку, гомілок неодноразово піддавалася сонячним опікам. Під час огляду на шкірі поперекової ділянки відзначено пляму з інтенсивним забарвленням до 5 мм у діаметрі, що відрізняється від інших утворень (симптом «гидкого каченяти»). Розміри утворення не дозволяють досконало оцінити його макроскопічно. Його складно вирізнити на фоні наявних поряд пігментних та внутрішньодермальних невусів, поодиноких вогнищ себорейного кератозу. При дерматоскопії утворення неоднорідне за рахунок ділянок високоінтенсивної поліхромної пігментації, які перемежовуються зонами регресу. Поодинокі глобули і точки розкидані хаотично, деякі з них розміщені на периферії утворення (рис. 12). Хворій рекомендовано виконати ексцизійну біопсію. Гістологічно підтверджено поверхнево-поширену меланому. Товщина за Бреслоу 1 мм без ознак звиразкування. Мінімальна дистанція від краю пухлини до ділянки ексцизії - 3 мм.

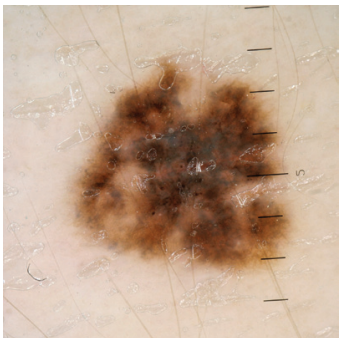

Рис. 12. Хвора В. Дерматоскопія із застосуванням світлопровідної рідини. Поверхнево-поширена меланома

Після встановлення діагнозу та виконання комплексу заходів з видалення первинної пухлини настає період диспансерного нагляду пацієнта. Основні завдання лікаря в цей час: забезпечити виявлення рецидиву хвороби (місцевого чи віддаленого) на ранніх етапах, запропонувати варіанти психосоціальної підтримки, забезпечити навчання щодо методів профілактики та самообстеження для хворого і близьких родичів, призначити і забезпечити ад'ювантну терапію, якщо вона показана, поліпшити раннє виявлення метахронної меланоцитарної чи безпігментної пухлини, розпізнавати та лікувати за наявності можливих побічних ефектів від ад'ювантного та паліативного лікування.

Тривалість і періодичність спостереження залежить від стадії первинної пухлини, наявності додаткових факторів ризику, таких як обтяжений сімейний анамнез, множинні пігментні невуси, сонячні опіки. Під час контрольних візитів рекомендується ретельна оцінка симптомів, про які повідомлено, фізичне обстеження рубця та навколишньої шкіри, фізикальне обстеження лімфатичних вузлів, загальноклінічне та дерматоскопічне обстеження шкіри, включаючи ділянку статевих органів, слизову оболонку рота та шкіру голови, аналіз крові на лактатдегідрогеназу та S-100. Критичними є перші 5 років після операції, оскільки 90\% усіх метастазів виявляють у цей час, проте, зважаючи на можливість виникнення пізніх метастазів, рекомендується подовжити період спостереження до 10 років. При цьому хворі зі стадіями IA-IIB для спостереження потребують лише фізикальне обстеження, дерматоскопію та ультразвукове дослідження лімфатичних вузлів як базових процедур, тоді як пацієнтам зі стадіями IIC-IV додатково проводять визначення рівнів лактатдегідрогенази та S-100, комп'ютерну чи позитронно-емісійну томографію, магнітно-резонансну томографію. Скорочений термін спостереження передбачається для хворих з IA-стадією, він може тривати 1 рік з 6-місячними проміжками між обстеженнями (Garbe C. et al., 2020a). За такою самою схемою, імовірно, варто спостерігати пацієнтів із меланомою in situ, не стільки в очікуванні метастазів, як для раннього виявлення подальших новоутворень.

Зважаючи на реалії нашої країни, де хворі з пухлинами шкіри розподіляються між лікарями кількох спеціальностей, важливою буде тісна співпраця між сімейними лікарями, дерматологами та онкологами для забезпечення ранньої діагностики, адекватного лікування, всесторонньої підтримки та грамотного спостереження пацієнтів із меланомою шкіри.

\section{Список використаної літератури}

Bauer J., Garbe C. (2003) Acquired Melanocytic Nevi as Risk Factor for Melanoma Development. A Comprehensive Review of Epidemiological Data. Pigment Cell Res., 16(3): 297-306. doi: 10.1034/j.1600-0749.2003.00047.x.

Elder D.E., Massi D., Scolyer R.A., Willemze R. (2018) WHO Classification of Skin Tumours. Fourth Edition (https://apps.who.int/bookorders/anglais/detart1.jsp?codlan=1\&codcol=70\&codcch=4011). 
Garbe C., Amaral T., Peris K. et al. (2020a) European consensus-based interdisciplinary guideline for melanoma. Part 1: Diagnostics - Update 2019. Eur. J. Cancer, 126: 141-158. https://doi.org/10.1016/j.ejca.2019.11.014.

Garbe C., Amaral T., Peris K. et al. (2020b) European consensus-based interdisciplinary guideline for melanoma. Part 2: Treatment - Update 2019. Eur. J. Cancer, 126: 159-177. https://doi.org/10.1016/i.ejca.2019.11.015

Gogas H., Eggermont A.M.M., Hauschild A. et al. (2009) Biomarkers in melanoma. Ann. Oncol., 20: 8-13. https://doi.org/10.1093/annonc/mdp251.

Herraiz C., Garcia-Borron J.C., Jiménez-Cervantes C., Olivares C. (2017) MC1R signaling. Intracellular partners and pathophysiological implications. Biochim. Biophys. Acta Mol. Basis. Dis., 1863(10 Pt. A): 2448-2461. doi: 10.1016/j. bbadis.2017.02.027.

Lee K.J., di Meo N., Yélamos 0., Malvehy J. (2020) Dermoscopy/Confocal Microscopy for Melanoma Diagnosis. In: Cutaneous Melanoma, 145-194 p. https://doi.org/10.1007/978-3-030-05070-2 50.

Mitra D., Luo X., Morgan A. et al. (2012) An ultraviolet-radiation-independent pathway to melanoma carcinogenesis in the red hair/fair skin background Nature, 491(7424): 449-453. https://doi.org/10.1038/nature11624.

Pizzichetta M.A., Talamini R., Stanganelli I. et al. (2004) Amelanotic/ hypomelanotic melanoma: clinical and dermoscopic features. Br. J. Dermatol., 150(6): 1117-1124. https://doi.org/10.1111/j.1365-2133.2004.05928.x.

Primiero C.A., McInerney-Leo A.M., Betz-Stablein B. et al. (2019) Evaluation of the efficacy of $3 \mathrm{D}$ total-body photography with sequential digital dermoscopy in a high-risk melanoma cohort: Protocol for a randomised controlled trial. BMJ Open, 9(11): e032969. https://doi.org/10.1136/bmjopen-2019-032969.

Ruiter D.J., Spatz A., van den Oord J.J., Cook M.G. (2002) Pathologic staging of melanoma. Seminars in Oncology, 29(4): 370-381. https://doi. org/10.1053/sonc. 2002.34116.

Salerni G., Carrera C., Lovatto L. et al. (2012) Benefits of total body photography and digital dermatoscopy ("two-step method of digital follow-up») in the early diagnosis of melanoma in patients at high risk for melanoma. J. Am. Acad. Dermatol., 67(1): e17-e27. https://doi.org/10.1016/j.jaad.2011.04.008.

Soyer H.P., Argenziano G., Hofmann-Wellenhof R., Johr R.H. (2007) Color atlas of melanocytic lesions of the skin. In: Color Atlas of Melanocytic Lesions of the Skin. https://doi.org/10.1007/978-3-540-35106-1.

Stolz W., Schiffner R., Burgdorf W.H.C. (2002) Dermatoscopy for facia pigmented skin lesions. Clinics in Dermatology, 20(3): 276-278. https://doi. org/10.1016/S0738-081X(02)00221-3

Valachis A., Ullenhag G.J. (2017) Discrepancy in BRAF status among patients with metastatic malignant melanoma: A meta-analysis. Eur. J. Cancer, 81: 106-115. https://doi.org/10.1016/j.ejca.2017.05.015.

Vuong K., Armstrong B.K., Drummond M. et al. (2020) Development and external validation study of a melanoma risk prediction model incorporating clinically assessed naevi and solar lentigines. Br. J. Dermatol., 182(5): 1262-1268. https://doi.org/10.1111/bjd.18411.

Whiteman D.C., Green A.C., Olsen C.M. (2016) The Growing Burden of Invasive Melanoma: Projections of Incidence Rates and Numbers of New Cases in Six Susceptible Populations through 2031. J. Invest. Dermatol., 136(6): 1161-1171. https://doi.org/10.1016/j.jid.2016.01.035

\section{Меланома кожи: от почти невидимой до визуально неоспоримой. Отдельные принципы руководства и обзор клинических случаев \\ М.С. Волошинович, И.А. Блага, Г.Е. Гирник, В.В. Голотюк, А.В. Калмыкова}

Резюме. Меланома - злокачественная опухоль, возникающая из меланоцитов, которая чаще поражает кожу, а также может возникать на роговице, конъюнктиве, цилиарном теле и любых местах, где локализована слизистая оболочка. Меланома - одна из самых опасных опухолей в силу способности к стремительному непрогнозируемому метастазированию. В Украине, согласно данным Национального канцер-реестра, заболеваемость в 2018-2019 гг. составляла 7,9 случаев на 100 тыс. населения. Важнейшим фенотипическим фактором риска меланомы считают кожу, склонную к возникновению солнечных ожогов. Она имеет генетическую детерминанту в виде наследственного варианта рецептора меланокортина-1, который участвует в опухолевом процессе. Меланома кожи делится на in situ и инвазивную, отличающихся локализацией атипичных клеток в границах эпидермиса или в нижележащих тканях соответственно. В свою очередь, среди инвазивных форм выделяют четыре наиболее распространенных типа: поверхностнораспространенную, нодулярную, меланому из злокачественного лентиго и акральную. Диагностика меланомы основывается, прежде всего, на клиническом осмотре больного. Однако с целью раннего выявления может быть использована дерматоскопия. Ее применение требует от специалиста комплекса знаний и навыков, которые постепенно растут с опытом практической работы. Ожидаемыми признаками являются: атипичная пигментная сеть, хаотично расположенные коричнево-черные пигментные глобулы или точки, асимметрично расположенные участки разноцветной пигментации, бело-голубая вуаль, полиморфный сосудистый рисунок. В случае выявления подозрительного образования необходимо его удаление с последующей гистологической верификацией. Если гистологический диагноз вызывает сомнения, дополнительную информацию можно получить с помощью иммуногистохимии. В публикации представлен обзор случаев заболевания различными формами меланомы кожи. Часть из них макроскопически очевидны, другие подтверждены дерматоскопически. Материал проиллюстрирован микрофотографиями с подробным описанием визуализированных структур. Кратко обобщены рекомендации по наблюдению больных с такой патологией.

Ключевые слова: меланома, диагностика, дерматоскопия, наблюдение, лечение.

\section{Skin melanoma: from almost invisible to visually indisputable. Some principles of guidance and clinical cases review}

\section{M.S. Voloshynovych, I.O. Blaga, G.Y. Girnyk V.V. Holotiuk, A.V. Kalmykova}

Summary. Melanoma is a malignant tumor that arises from melanocytes and most often affects the skin. This tumor can also occur on the cornea, conjunctiva, ciliary body, and any place where the mucous membrane is localized. Melanoma is one of the most dangerous tumors due to its ability to rapidly unpredictable metastasis. In Ukraine, according to the National Cancer Registry, the incidence as of 2018-2019 was 7.9 cases per 100,000 population. The most important phenotypic risk factor is the skin prone to sunburn. It has a genetic determinant in the form of a hereditary variant of the melanocortin-1 receptor, which is involved in the tumor process. Melanoma of the skin is divided into «in situ» and «invasive», which differ in the localization of atypical cells in the smears of the epidermis and in the underlying tissues, respectively. In turn, among the invasive forms there are four most common types: superficial, nodular, melanoma of malignant lentigo and acral. Diagnosis of melanoma is based primarily on the clinical examination of the patient. However, dermatoscopy may be used for early detection. Its application requires from the specialist a set of knowledge and skills that will gradually grow with the experience of practical work. Expected signs will be the next: atypical pigment network, chaotically located brown-black pigment globules or dots, asymmetrically placed areas of multicolored pigmentation, whiteblue veil, polymorphic vascular pattern. If a suspicious formation is detected, it should be removed, followed by histological verification. In cases where the histological diagnosis is in doubt, additional information can be obtained from immunohistochemistry. The publication presents an overview of various forms of skin melanoma cases. Some of them are macroscopically obvious, others are confirmed dermatoscopically. The material is illustrated with micrographs, with a detailed description of the visualized structures. Recommendations for monitoring patients with this pathology are briefly summarized.

Key words: melanoma, diagnosis, dermatoscopy, observation, treatment.

\section{Адреса для листування:}

Волошинович Мар'ян Стефанович

76018, м. Івано-Франківськ, вул. Кропивницького, 16

Івано-Франківський національний медичний університет,

кафедра дерматології та венерології

E-mail: mvoloshynovych@gmail.com

Одержано 25.06.2020 